Филолошки факултет

\title{
КУЛТУРНА ИНТЕЛИГЕНЦИЈА КАО ВИШЕДИМЕНЗИОНАЛНА КОМПЕТЕНЦИЈА КОЈА СПАЈА КУЛТУРУ И НАУКУ ${ }^{1}$
}

\section{Сажетак}

Истраживање представљено у овом раду бави се културном интелигенцијом као компетенцијом која је неопходна за контекст плуралистичких друштава. Етос плурализације намеће важност културне интелигенције као вештине која доприноси не само бољој комуникацији у мултикултуралној средини, већ и смањивању друштвене категоризације. Стога се у овом раду осврћемо на однос између културне интелигенције и креативности и успешности, уз анализу резултата националних истраживања која су до сада обављена у многим државама, са циљем извођења релевантних закључака.

Кључне речи: културна интелигенција, мултикултурална средина, креативност, успешност у пословном окружењу

\section{1. Увод}

Културна интелигенција је концепт који указује на то да ли је и у коликој мери појединац способан да се носи са различитим културним контекстима у којима се неретко налазе и други појединци из културног миљеа другачијег од нашег (Earley and Ang 2003). Овом дефиницијом

1 Овај рад је део истраживања која се изводе на пројекту Друштвене кризе и савремена српска књижевност и култура: национални, регионални, европски и глобални оквир (бр. 178018), који финансира Министарство просвете и науке Републике Србије. 
Ерли и Анг (2003) развили су појам културне интелигенције, која се обележава скраћеницом CQ (енг. Cultural Quotient). Она се данас сматра посебним видом интелигенције (Erez et al. 2013), а чине је четири кључне димензије: когнитивна, метакогнитивна, мотивациона и бихевиорална (Earley and Ang 2003). У овом раду бавићемо се метакогнитивном и мотивационом културном интелигенцијом због њихове доказане повезаности са појмовима као што су креативност и успех у раду (Bogilovic and Skerlavaj 2016) и утицаја који та веза може имати на однос између науке и праксе у појединачним културама. Област изучавања културне интелигенције је, у научном смислу, још увек у повоју, нарочито на европском континенту, али је прва деценија двадесет и првог века донела известан број конкретних студија случаја које указују на њен допринос у академској и пословној средини. С обзиром на то да су метакогнитивне вештине заслужне за креативно размишљање (Fledhusen and Goh 1995), научници сматрају да су појединци са развијеном метакогнтивном културном интелигенцијом сналажљивији и прилагодљивији, те да у културно „изазовним“ ситуацијама доносе адекватније одлуке. Анг и други (2007) доказали су да појединци који поседују високу метакогнитивну културну интелигенцију паметније планирају своје реакције у интеракцији с колегама из различитих култура, односно да су свесни неопходних менталних измена које се од њих у датом тренутку очекују.

Због свега наведеног, циљ овог рада биће да упозна читаоца са релевантном литературом, како са теоријским основама културне интелигенције, тако и са истраживањима која потврђују постојање многобројних веза између овог појма и академског, односно, пословног света. Структура рада огледаће горе истакнуте циљеве, представљена у две међусобно повезане целине. Поред закључка, овај рад нуди и осврт на практичне импликације и потенцијал будућих истраживања у која би било корисно укључити и студенте. Када је у питању постојећа литература, теоријски део овога рада ослања се на до сада објављене радове Дејвида К. Томаса и Кера Инксона који су понудили детаљан преглед све четири димензије културне интелигенције уз јасне примере и елементе емпиријских истраживања, док је у другом делу рада фокус усмерен на резултате конкретних студија случаја, нарочито у регионално блиском контексту: Словенији, Молдавији и Украјини. 
Култура и/или наука

\section{2. Теоријски осврт на појам културне интелигенције}

Културна интелигенција се стиче и „подразумева ширину и умеће у разумевању поједине културе, пораст знања о тој култури кроз личну интеракцију с њом, постепено мењање сопственог размишљања у смеру бољег разумевања дате културе и унапређивање понашања у циљу постизања веће умешности и примерености у интеракцији са припадницима те културе“ (Tomas i Inkson 2011: 29). Према Томасу и Инксону, постоје три параметра на основу којих појединац може проценити сопствену културну интелигенцију: знање, свесност и вештине (Tomas i Inkson 2011). Под појмом знања се подразумева то да особа разуме дефиниције културе, основне разлике између култура и везу између културе и њене реализације у свакодневном животу. Знање, пак, не мора бити довољно, већ је неопходна и свесност. Свесност се пре свега односи на промишљено усмеравање пажње на присуство друге културе, онда када се особа с културном интелигенцијом нађе у таквој ситуацији, и примену прилагођеног знања у датом контексту. Трећи сегмент су вештине, које представљају спој знања, свесности и искуства. Искуство зависи од броја културно разноликих ситуација у којима се појединац нађе и изграђеног осећаја за процену, односно, меру. Приказ компонената културне интелигенције налази се на Слици 1 (Tomas i Inkson 2011: 31).

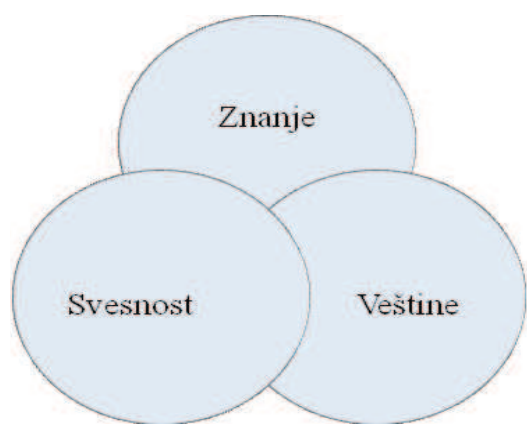

Слика 1.

Културна интелиганција заправо поседује елементе и других конструката који се у психологији називају различитим врстама интелигенције (Tomas i Inkson 2011). Мера која се назива количник интелигенције - IQ представља способност резоновања; емоционал- 
на интелигенција - EQ је показатељ нашег управљања осећањима (Selman et al. 2005); док културна интелигенција подразумева и резоновање и управљање емоцијама, али у интеракцији са припадницима других култура. Узмимо за пример ситуацију у ресторану у Шангају у којој су главни актери Кинез, домаћин, и Британац, гост:

Чан Јун Фаи извео је свог госта Британца у један ресторан, а затим му за столом рекао да мисли да храна у том ресторану није баш најквалитетнија. Британац се на то збунио и упитао се зашто би га домаћин извео у ресторан за који сматра да је лош. Почео је да размишља о разлозима због којих би Чан тако нешто рекао. Сетио се да је негде чуо да су Кинези скромни. Помислио је да је можда у томе тајна. Можда не треба да хвали ресторан? Затим примети да га Чан гледа, очигледно очекујући одговор или реакцију и рече: „Сигуран сам да ћемо је искористити најбоље што можемо“. Осмех на лицу господина Јун Фаиа нестаде. Британац у овој ситуацији није био упознат са кинеским обичајем изражавања поштовања према госту тако што се умањује вредност или значај личних способности, или у овом случају одабира ресторана. Ипак, Кинези очекују да се на тај обичај одговори комплиментом, што је у горе наведеном примеру изостало. Гост из нашег примера био је свестан културних разлика, али мањак знања и вештина довео је до грубе увреде домаћина. (прилагођено из: Cusher and Brislin 1996)

Као што је истакнуто на почетку, да би појединац развио културну интелигенцију, мора поседовати основно знање о томе шта култура јесте. Гудинаф сматра да се „култура једног друштва састоји од свега онога што појединац треба да зна или верује како би могао да се понаша на начин прихватљив члановима тог друштва. Култура није материјални феномен: не састоји се од ствари, људи, понашања или емоција. [...] То је облик те организације који људи имају у свести“ (Goodenough 1957: 167). Познати социолог Герт Хофстеде слаже се са овом дефиницијом и истиче да културу чине ментални програми који дефинишу начин на који ми, као појединци, доживљавамо окружење и одговарамо на културне импулсе (Hofstede 1980). Без обзира на комплексност дефиниције културе, теоретичари су сагласни око једног, а то је чињеница да је култура дубоко укорењена, те да су све спољашње реализације само израз скривених, усвојених, културолошких елемената.

Томас и Инксон истичу да, на менталном плану, људска врста поседује карактеристике које су свима заједничке - потре- 
ба за преживљавањем, глад, жеђ, физиолошке потребе, одбрана територије и потреба за размножавањем и чувањем потомака (Tomas i Inkson 2011). На имагинарној пирамиди менталних нивоа, ове заједничке карактеристике могле би се наћи у основи пирамиде, као централне одлике свих припадника људског рода. На врху пирамиде се, пак, налази личност, која се заснива на комбинацији генетике и појединачних искустава, средине и спољашњих утицаја. Средњи ниво је ниво ком припада оно што називамо културом, ниво који делимо са осталим припадницима наше уже или шире заједнице. „Управо је заједничко програмирање ума оно што омогућава припадницима једне групе посебну блискост у односима, која је онима који не припадају тој групи ускраћена“ (Tomas i Inkson 2011: 38).

Знање, међутим, мора бити употпуњено свесношћу која подразумева „обраћање пажње на контекст и одбацивање круте испрограмираности ума“ (Tomas i Inkson 2011: 36). То не значи да треба да заборавимо ко смо и каква је наша култура, већ само да се усредсредимо на присуство друге културе и потенцијалне разлике између наше и оне која је пред нама. Свесност се, према Томасу и Инксону, састоји од свесне пажње, свесног праћења и свесног управљања, а постојање сва три елемента нам омогућава лагодност у интеракцији са другим културама. Последњи ниво, ниво вештина, резултат је акумулације искуства и доводи нас до закључка да поседовање или развијање културне интелигенције не подразумева стицање вештина комуникације за одређену групу или врсту понашања; културна интелигенција је збир општих вештина које су део спектра ситуација или контекста на основу којих ми проширујемо могућности деловања и доносимо одлуке у већ познатим или потпуно новим ситуацијама (Tomas i Inkson 2011).

Говиндарајан и Гупта процењују да постоји укупно пет стадијума стицања културне интелигенције. Прва два стадијума односе се на буђење горе описане свесности и препознавање сложености искуства, друга два на акомодацију и асимилацију наученог у наше моделе деловања, док се пети стадијум односи на тзв. проактивност (Govindarajan and Gupta 2001). Особа која је достигла пети стадијум има до те мере изоштрен осећај за реаговање у најразличитијим ситуацијама да уме да опажа и најсуптилније детаље у интеракцији. Оваквих особа је, ипак, мало, с обзиром на то да већина светске 
популације нема много прилика за стицање културно разноликог искуства. Релевантном искуству доприносе путовања и учење страних језика (Johnson 2014), али ће о значају истих бити више речи у следећем поглављу. Оно што је такође важно истаћи јесте чињеница да је надградња културне интелигенције процес који се не развија увек истим ритмом, већ уз честе паузе (осим у случају особа које на свакодневном нивоу сарађују са особама из других култура), те се може приказати кривудавом испрекиданом линијом као на Слици 2 (прилагођено из: Govindarajan and Gupta 2001).

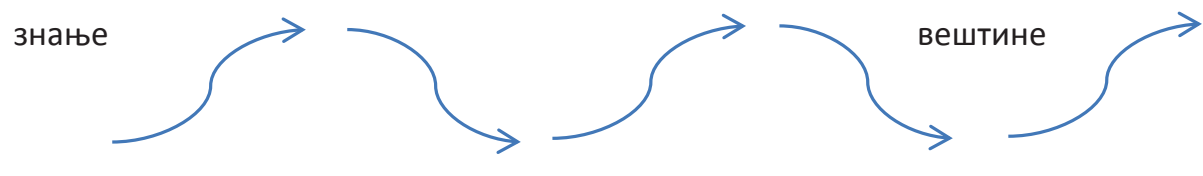

Слика 2.

Општи закључак, за све оне који немају директних прилика за међународно искуство као резултат путовања или живота у некој другој земљи, јесте да постоји неколико корака који се могу предузети на путу ка културној интелигенцији, без обзира на личне/групне околности. Први корак је упознавање са сопственом културом, као и стереотипима које наша култура гаји према припадницима других култура. Такође је изузетно значајно истражити елементе сопствене културе који би могли утицати на реакције појединца у интеркултуралној комуникацији. Следећи корак је свесно одбацивање несвесности и адекватно прилагођавање конкретним ситуацијама. Уз то, важно је проверити и повратну информацију, односно да ли наш доживљај ситуације и реакција на исту одговарају присутнима, како бисмо потврдили да смо на правом путу. На крају преостају развијање опште отворености ка новим „културно разноврсним“ ситуацијама, да бисмо се без бојазни упуштали у непознато, као и незаобилазна пракса.

У овом поглављу разјаснили смо три компоненте културне интелигенције: знање, свесност и вештине, уз појединачна објашњења сваке од компоненти. Исто тако, представили смо пут стицања културне интелигенције као процеса који се састоји од пет стадијума, а за који је потребно како лично ангажовање у оквиру сопствене културе, тако и предано излагање иностраном окружењу. Следеће поглавље износи 
Култура и/или наука

до сада спроведена емпиријска истраживања, закључке и импликације за будућност које отварају простор новим истраживачким хипотезама.

\section{3. Анализа досадашњих истраживања и резултати студија на тему културне интелигенције}

Бојд Џонсон, професор на Универзитету у Индијани, објашњава да је концепт културне компетенције, који се сматра дериватом културног образовања и културне осетљивости, у честој употреби у круговима социолога у источној Европи, али се термин културна интелигенција сматра релативно новим, нарочито у државама бившег Совјетског савеза и југоисточне Европе (Johnson 2014). Важно је, наглашава он, бавити се културном интелигенцијом у оваквим земљама јер се оне и даље налазе у процесу транзиције који води ка Европској унији, још већој мобилности међу људима и значајној размени информација у друштву европских држава без граница.

Културна интелигенција (CQ) мери се на основу скале која се састоји од укупно 20 ставки. Скалу за мерење културне интелигенције (Cultural Intelligence Scale - CQS) развили су Анг и други 2007. године, а од тада су у горе поменутом региону спроведене четири националне студије - у Украјини, Молдавији, Словенији и Србији (истраживање је у току). До сада спроведена истраживања заснована су на моделу истраживања Анг и други (2007) и Анг, Ван Дин и Кох (2006), а према њима CQS чине четири међусобно повезане целине које представљају појам интелигенције као појам комплексне, вишесложне и личне природе (Johnson 2014): метакогнитивна културна интелигенције је ментална способност појединца да разуме и усвоји културно знање; когнитивна културна интелигенција указује на опште знање о култури; мотивациона културна интелигенција је огледало способности појединца да усмери своју вољу и енергију, да научи нешто ново и да се успешно снађе у културно разноврсним ситуацијама; последња у структури CQS-a је бихевиорална културна интелигенција, мерило могућности појединца да на контекстуално одговарајућ начин користи елементе вербалне и невербалне комуникације.

Џонсон је у свом истраживању у Украјини (2014) показао да постоји позитиван однос између метакогнитивне, мотивационе и бихевиоралне културне интелигенције и међународног ис- 
куства. Хипотеза је постављена на основу истраживања Шенон и Бегли (2008) који су тестирали однос између радног искуства у међународном окружењу и CQ. Показало се да сваки облик радног искуства који захтева интеракцију са припадницима других култура и прилагођену комуникацију повећава прилагодљивост и флексибилност појединаца у контекстима који могу, али не морају, водити ка сукобима у пословном окружењу. Изложеност ономе што научници називају међународним искуством мерена је на основу (1) боравка у страној земљи након 14. године, (2) живота у страној земљи након 14. године, (3) познанстава/пријатељстава са људима који су из стране земље, (4) познанстава/пријатељстава са људима који су из матичне земље али живе у иностранству, и (5) родбинских веза са људима који живе у иностранству, а са којима је појединац у редовном контакту (Shannon and Begley 2008).

Такође, истраживање је указало на то да постоји позитиван однос између културне интелигенције и учења страних језика. Сматрамо да је ово значајно поље које треба даље истражити с обзиром на то да представља плодно тле за приближавање различитих култура и развијање културне интелигенције код појединаца који, услед различитих околности, немају услова за испуњавање ниједног од горе наведених пет услова за унапређење CQ. Учење језика је суптилан начин усвајања културе језика који се учи, те аутоматски и квалитетан инструмент за преношење културног знања (Johnson 2014). Резултати нивоа културне интелигенције између анкетираних појединаца који не говоре ниједан језик осим матерњег и оних који говоре макар још један страни језик на средњем ниову су више него видљиви. Ови резултати одговарају резултатима до којих су научници дошли у Америци, Сингапуру и Ирској, а затим и у Молдавији и Словенији, те се очекује да ће се до сличних резултата доћи у Републици Србији, где је национална студија на тему културне интелигенције започета 2016. године.

Када је Словенија у питању, фокус је усмерен на везу између креативности и културне интелигенције, пре свега метакогнитивне и мотивационе културне интелигенције. Богиловић и Шкерлавај (2016) пошле су од тезе да је неупитан утицај креативности на радно окружење, али да и даље нема довољно истраживања на тему креативности у културно разноликом окружењу. Креативност води ка 
Култура и/или наука

иновативности, ка новим идејама (Amabile et al. 1996), посебно међу запосленима у корпоративној средини (Shalley and Gilson 2004; Zhou and Shalley 2011). Доказано је да културне разлике међу запосленима воде до оригиналних начина решавања задатака, примене нових стилова, знања и вештина (Pelled, Eisenhardt and Xin 1999; Williams and O'Reilly 1998), те културне различитости могу бити значајан извор како креативности тако и пословне ефикасности (Amabile 1996).

Са друге стране, Пфефер (1983) запажа да културна разноликост не само да не може да развије културну интелигенцију, већ да може да је умањи, захваљујући процесу који се назива друштвена категоризација (енг. social categorization). Тајфел и Тарнер (1986) спровели су истраживање чији резултати сведоче да боравак или рад са припадницима других култура додатно наглашава културне разлике, те да разлике воде до груписања на оне који припадају доминантној групи и оне који припадају осталим етничким, националним, културним или другим групама. Штавише, даља истраживања показала су да различитост и плуралитет могу водити ка директним конфликтима, што свакако није у позитивним односу са креативношћу, у било којој средини, а нарочито пословној, која захтева тимски рад и неометану сарадњу великог броја појединаца (Bogilovic and Skerlavaj 2016). Овако супротстављени ставови указују на то да истраживањима о културној интелигенцији треба да приђемо обазриво и да будемо свесни околности које воде од различитости до поделе и сукоба. Међутим, први корак, према Рокштулу и Нгу, јесте развијена метакогнитивна културна интелигенција, односно свест да око нас живе и раде особе различитог културног порекла од нас и да нас та свест спречава да „правимо површне и нетачне закључке на основу видљивих етничких разлика" (Rockstuhl and Ng 2008: 210).

Ако се вратимо у регион југоисточне Европе и истраживање спроведено у Словенији, Богиловић и Шкерлавај (2016) потврдиле су хипотезу да метакогнитивна и мотивациона културна интелигенција позитивно корелирају са креативношћу појединца. У њиховом истраживању, које је спроведено у 20 компанија у јадранској регији, учествовало је 787 запослених. Обе димензије културне интелигенције мерене су на основу Анг и Ван Дин (2008), а упитник садржи исказе као што су:

Метакогнитивна културна интелигенција: 
Свестан/а сам културног знања које користим када се налазим у интеракцији са људима различитог кулурног порекла.

Прилагођавам своје културно знање када сам у интеракцији са људима из културе која ми је непозната.

Мотивациона културна интелигенција:

Уживам да будем у интеракцији са људима из различитих култура.

Сигуран/а сам да могу да се носим са стресом прилагођавања култури која ми је нова.

Овим истраживањем дат је одговор на многобројне позиве на детаљну анализу односа између креативности и диверзитета (Anderson et al. 2004), а емпиријски је потврђено да културна разноврсност подстиче креативност код појединаца. Ауторке истраживања истичу да резултате студије не треба задржати на теоријском нивоу већ да треба све више указивати на практичне импликације култуне интелигенције. На пример, менаџери и послодавци широм света могу у својим компанијама да створе културно разноврсне средине како би утицали на развој културне интелигенције код својих запослених, подстакли сарадњу, тимски рад и свеукупну ефикасност (Elenkov and Manev 2009). Такође, јавни и приватни сектор могу узети у обзир слање запослених на усавршавање у иностранство како би их сензитивисали ка другачијим начинима размишљања, управљања и решавања проблема (Li et al. 2013). Чак треба размотрити и опције дугорочног боравка у иностраном пословном окружењу јер је дужина боравка директно повезана са порастом културне интелигенције.

\section{4. Закључак}

Оно што остаје као закључак јесу питања која теорија и постојеће студије случаја отварају као подстрек за будућа истраживања. Пре свега, сматра се да истраживања о културној интелигенцији све више треба да буду усмерена ка ученицима и студентима, те да треба покренути развој културне интелигенције код младих док су још у периоду изградње и обликовања личности. Досадашња истраживања умногоме су се бавила корпоративним окружењем, што је свакако од велике важности, али треба скренути пажњу и ка другим сегментима 
Култура и/или наука

друштва и друштвених делатности.

Као друго, треба отићи још један корак уназад и анализирати карактеристике особа које су склоније успешнијем развијању културне интелигенције како би се сличне карактеристике подстицале код младих особа од раног узраста. Поставља се питање да ли је то заиста потребно за све, али како сматра Урнаутова, глобализација намеће развијање кутурне интелигенције јер су у данашње време и особе које немају много прилика да бораве ван матичне земље окружене међународним компанијама и све већим бројем досељеника који доносе са собом своју културу (Urnaut 2014). Даунс, Варнер и Хемаси (2010) препознали су, стога, „велику четворку“ карактеристика које треба неговати, а то су екстровертност (интеркација са спољним светом и усмереност на друге људе), емотивна стабилност (способност ношења са стресом), отвореност (радозналост и спремност за упуштање у непознато и ново) и сарадљивост (способност повезивања и стварања друштвених односа). У вези са тим, осим ових карактеристика, треба развијати и друге видове интелигенција, што у значајној мери олакшава лично надограђивање на културну интелигенцију и разумевање исте. Посебну пажњу треба пружити емоционалној интелигенцији, коју су као појам увели Саловеј и Мејер (1990), и на време стећи вештине праћења сопствених и туђих осећања, а све у циљу бољег управљања понашањем, односима и свакодневним корацима (Bradberry and Greaves 2009).

\section{Извори и литература}

Amabile, T. Creativity in Context. Boulder, CO: Westview Press, 1996. Print.

Amabile T. M., Conti, R., Coon, H., Lazenby, J. and Herron, M. Assessing the Work Environment for Creativity. Academy of Management Journal 39:5 (1996): 1154-1184. Print.

Anderson, N., De Dreu, C. K. and Nijstad, B. A. The routinization of innovation research: A constructively critical review of the state-of-the-science. Journal of Organizational Behavior 25:2 (2004): 147-173. Print.

Ang, S. et al. Cultural Intelligence: Its Measurements and Effects on Cultural Judgement and Decision-Making, Cultural Adaptation, and Task Performance. Management and Organization Review 3:3 (2007): 335-371. Print.

Ang, S., Van Dyne, L. and Koh, C. K. S. Personality Correlates of the Four Factor Model of Cultural Intelligence. Group and Organization Management 31:1 (2006): 100123. Print. 
Ang, S. and Van Dyne, L. Conceptualization of Cultural Intelligence: Definition, Distinctiveness, and Nomological Network. In: Ang, S. and Van Dyne, L. (Eds.), Handbook of Cultural Intelligence: Theory, Measurement, and Application. Armonk, NY: M.E. Sharpe, 2008. 3-15. Print.

Bogilovic, S. and Skerlavaj, M. Metacognitive and Motivational Cultural Intelligence: Superpowers for Creativity in a Culturally Diverse Environment. Economic and Business Review 18:1 (2016): 55-76. Print.

Bradberry, T. and Greaves, J. Emotional Intelligence 2.0. San Diego: TalentSmart, 2009. Print.

Cusher, K. and Brislin, R. W. Intercultural Interactions: A Practical Guide. Thousand Oaks, CA: Sage, 1996. Print.

Downes, M., Varner, I. and Hemmasi, M. Individual Profiles as Predictors of Expatriate Effectiveness. Competitiveness Review: An International Business Journal 20:3 (2010): 235-247. Web. 30.01.2018.

Earley, P. C. and Ang, S. Cultural Intelligence: An Analysis of Individual Interactions across Cultures. Palo Alto (CA): Stanford University Press, 2003. Print.

Elenkov, D. S. and Manev, I. M. Senior Expatriate Leadership's Effects on Innovation and the Role of Cultural Intelligence. Journal of World Business 44:4 (2009): 357-369. Print.

Erez, M., Lisak, A., Hatush, R., Glikson, E., Nouri, R. and Shokfef, E. Going Global: Developing Management Studens' Cultural Intelligence and Global Identity in Culturally Diverse Virtual Teams. Academy of Management Learning \& Education 12:3 (2013): 330-355. Print.

Fledhusen, J. F. and Goh, B. E. Assessing and Accessing Creativity: An Integrative Review of Theory, Research and Development. Creativity Research Journal 8:3 (1995): 231-247. Print.

Goodenough, W. H. Cultural Anthropology and Linguistics. In: Garvin, P.L. (Ed.), Report on the 7th Annual Round Table Meeting in Linguistics and Language Study. Washington/DC: Georgetown University, 1957. 109-173. Print.

Govindarajan, V. and Gupta, A. The Quest for Global Dominance. San Francisco: JosseyBass, 2001. Print.

Hofstede, G. Culture's Consequences: International Differences in Work Related Values. Beverly Hills, CA: Sage, 1980. Print.

Johnson, B. Testing Cultural Intelligence of Ukrainian Students. ЕКОНОМІЧНИЙ НОБЕЛІВСЬКИЙ ВІСНИК, 1:7 (2014): 171-178. Print.

Li, M., Mobley, W. and Kelly, A. When Do Global Leaders Learn Best to Develop Cultural Intelligence? An Investigation of the Moderating Role of Experiential Learning Style. Academy of Management Learning \& Education 12:1 (2013): 32-50. Print.

Pelled, L. H., Eisenhardt, K. M. and Xin K. R. Exploring the Black Box: An Analysis of Work Group Diversity, Conflict and Performance. Administrative Science Quarterly 44:1 (1999): 1-28. Print.

Pfeffer, J. Organizational Demography. Research in Organizational Behavior 5 (1983): 299-357. Print.

Rockstuhl, T. and Ng, K. Y. The Effects of Cultural Intelligence on Interpersonal Trust in Multicultural Teams. In: Ang, S. and Van Dyne, L. (Eds.), Handbook of Cultural Intelligence: Theory, Measurement and Applications. New York: M. E. Sharpe, 2008. 206-220. Print. 
Култура и/или наука

Salovey, P. and Mayer, J. D. Emotional intelligence. Imagination, Cognition, and Personality 9:3 (1990): 185-211. Print.

Selman, V., Selman, R., Selman, J. and Selman, E. Spiritual-Intelligence/-Quotient. College Teaching Methods \& Styles Journal 1:3 (2005): 23-30. Web. 30.01.2018.

Shalley, C. E. and Gilson, L. L. What Leaders Need to Know: A Review of Social and Contextual Factors That Can Foster or Hinder Creativity. The Leadership Quarterly 15:1 (2004): 33-53. Print.

Shannon, L. and Begley, T. Antecedents of the Four-Factor Model of Cultural Intelligence. In: Ang, S. and Van Dyne, L. (Eds.), Handbook of Cultural Intelligence: Theory, Measurement, and Application. Armonk, NY: M.E. Sharpe, 2008. 41-55. Print.

Tajfel, H. and Turner, J. C. The Social Identity Theory of Intergroup Behavior. In: S. Worchel, S. and Austin, W. (Eds.), Psychology of Intergroup Relations. Chicago, IL: Nelson-Hall, 1986. 7-24. Print.

Tomas, D. K. i Inkson, K. Kulturna inteligencija: Živeti i raditi globalno. Beograd: Clio, 2011. Print.

Urnaut, A. G. Education for Successful Intercultural Communication and Cultural Intelligence. Journal of Economic and Social Development 1:1 (2014): 63-73. Print.

Williams, K. Y. and O'Reilly, C. A. Demography and Diversity in Organizations: A Review of 40 Years of Research. In: Staw, B.M. and Sutton, R. (Eds.), Research in Organizational Behavior (Vol. 20). Greenwich, CT: JAI, 1998. 77-140. Print.

Zhou, J. and Shalley, C. E. Deepening Our Understanding of Creativity in the Workplace: A Review of Different Approaches to Creativity Research. In: Zedeck, S. (Ed.), APA Handbook of Industrial and Organizational Psychology (Vol. 1). Washington, DC: Psychological Association, 2011. 275-302. Print.

\author{
Biljana Djoric Francuski \\ Tara Djelic \\ University of Belgrade \\ Faculty of Philology
}

\title{
CULTURAL INTELLIGENCE AS A MULTIDIMENSIONAL COMPETENCE BRIDGING CULTURE AND SCIENCE
}

\section{Summary}

The aim of this research is to look into the concept of cultural intelligence (CQ) as an indispensable competence in pluralistic societies. Pluralization ethos lays emphasis 
on cultural intelligence as a skill which not only increases the quality of inter-personal communication in a multicultural context, but also decreases social categorization. Therefore, this research focuses on the relationship between cultural intelligence and creativity, success in a business environment, and overall individual accomplishment. When it comes to research methodology, the first part of the paper presents relevant definitions of both culture and cultural intelligence, as well as lays the foundation of cultural intelligence in understanding one's own culture. The second part of the paper focuses on the relationship between cultural intelligence, creativity and business environment. Recent research shows that students and employees whose motivational cultural intelligence is developed and who have the ability to (re)shape their attitute towards other cultures, that is, those whose metacognitive cultural intelligence is more advanced, are more creative. Furthermore, multicultural environment offers new forms of problem-solving, knowledge, work style and skills which improve academic/ professional performance and boost cultural intelligence in students and employees. The given hypothesis will be corroborated by the results of national research thus far carried out in Ukraine, Moldova and Slovenia. Finally, the overall aim of this paper is to point to the need for further research of cultural intelligence in Serbia, particularly with regard to cultural intelligence of university students and that of employees in public and private companies. 